Special issue of the International Conference on Computational and Experimental Science and Engineering (ICCESEN 2014)

\title{
In Vitro Analysis of AHPlus and MM-Seal by ESR and Thermoanalytical Methods
}

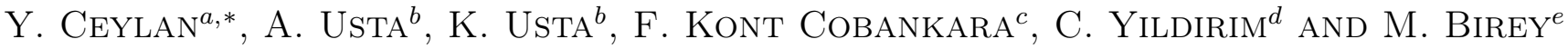 \\ ${ }^{a}$ Selcuk University, Faculty of Science, Department of Physics, Konya, Turkey \\ ${ }^{b}$ Alanya Alaaddin Keykubat University, Alanya Engineering Faculty, Alanya, Antalya, Turkey \\ ${ }^{c}$ Department of Endodontics, Faculty of Dentistry, University of Selcuk, Konya, Turkey \\ ${ }^{d}$ Department of Endodontics, Faculty of Dentistry, University of Gaziantep, Gaziantep, Turkey \\ ${ }^{e}$ Department of Physics, Faculty of Science University of Ankara, Ankara, Turkey
}

\begin{abstract}
The free radicals and their concentration in resin materials may impact biocompatibility and polymerization properties of dental materials. The aim of this study was to determine whether there are free radicals and to obtain useful information about thermal stability of materials using electron spin resonance (ESR) spectroscopy, TGA (Thermogravimetry Analysis) and DTA (Differential Thermal Analysis) methods. Epoxy resin-based sealers AHPlus and MM-Seal samples, freshly mixed and set, were prepared to be analysed with ESR and thermal methods. The free radicals were found in dental materials. As radical concentration in AHPlus have changed very slowly, the concentration in MM-Seal have decreased dramatically. Also, MM-Seal was found to decompose in three steps with the increasing temperature, while decomposition of the AHPlus occurred in two steps.
\end{abstract}

DOI: 10.12693/APhysPolA.128.B-479

PACS: 87.66.Uv, 36.20.Kd, 39.30.+w, 33.35. $+\mathrm{r}$

\section{Introduction}

The biocompatibility of endodontic materials is important for the clinical success of endodontic therapy. If these materials have toxic characteristics, then they may cause inflammatory reactions in periapical tissues $[1,2]$ and can interact with biomolecules in tissues. This interaction can damage living tissues [3-6]. Recently, the materials with toxic characteristics have been determined by using various methods [7-10]. Electron spin resonance (ESR) may be an appropriate method to investigate the materials with radical structures, having cytotoxic properties $[11,12]$. The thermal analysis methods have been used to obtain useful information about thermal stability of materials and also to determine the temperature ranges in which they can be used without changes in their composition, color and structural properties $[13,14]$. In vitro methods have been recommended by the American National Standards Institute, the American Dental Association [15] for evaluation of the cytotoxicity of endodontic materials. For biomedical applications using new polymeric composite materials, it is significant to know quantively the amount of residual monomer release from the surface of the polymerized composite, because of the likely harmful effects of residual monomers on tissues [16-25]. It is well known that oxygen presence inhibits free radical polymerization of monomers of the resin. Therefore, the surface layer may contain residual monomers with unpaired electrons [26, 27].

\footnotetext{
* corresponding author; e-mail yceylan@selcuk.edu.tr
}

In this study, AHPlus (Dentsply, DeTrey, Konstanz, Germany) and MM-Seal (Micro-Mega, Besancon, Cedex, France) root canal sealers were investigated using in vitro methods, such as ESR and the thermal analysis methods (thermogravimetry analysis (TGA) and differential thermal analysis (DTA)). AHPlus and MM-Seal are epoxy resin-based sealers. AHPlus consists of two-component paste root canal sealer, based on polymerization reaction of epoxy resin-amines.

\section{Experimental}

Trade names, manufacturer, and ingredients of the materials used in the present study are listed in Table I. The samples were mixed according to manufacturer's instructions. AHPlus and MM-Seal samples, freshly mixed and set, were prepared. The freshly prepared endodontic sealers were left in a humid chamber at $37^{\circ} \mathrm{C}$.

ESR measurements were carried out in aerobic environment between $25^{\circ} \mathrm{C}$ and $37^{\circ} \mathrm{C}$ using ESR X-BandBruker EMX 081 spectrometer (Rheinstetten, Germany) in Saraykoy laboratory of TAEK (Turkish Atomic Energy Authority). Freshly mixed samples were placed into the quartz tubes with a diameter of $4 \mathrm{~mm}$ using a teflon bar, in the same way the set samples with surface area of about $2 \mathrm{~mm}^{2}$ and thickness of $1 \mathrm{~mm}$ were placed in cylindrical quartz tubes with diameter of $4 \mathrm{~mm}$. The set samples were stored in a humid environment at $37^{\circ} \mathrm{C}$. The $g$-factor was found by comparison with a DPPH sample $(g=2.0036)$.

Thermo-analytical TGA, DTG, and DTA curves were obtained simultaneously by using a Shimadzu DTG-60H Thermal Analyzer. Thermal measurements were performed under flow of nitrogen and air atmosphere with 
TABLE I

Composition of the resin-based sealers used in this study.

\begin{tabular}{|c|c|c|}
\hline Sealers & Manufacturer & 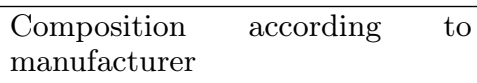 \\
\hline \multirow[t]{2}{*}{ MM-Seal } & $\begin{array}{l}\text { Micro-Mega, } \\
\text { Besancon, } \\
\text { Cedex, France }\end{array}$ & $\begin{array}{l}\text { Base epoxy oligomer resin }(29 \%) \text {, } \\
\text { ethylene glycol salicytate }(18 \%) \text {, } \\
\text { calcium phosphate }(17 \%) \text {, bis- } \\
\text { muth subcarbonate }(26 \%) \text {, zirco- } \\
\text { nium oxide }(10 \%)\end{array}$ \\
\hline & & $\begin{array}{l}\text { Catalyst: Polyaminobenzoate } \\
(31 \%), \text { triethan olamine }(5 \%) \text {, } \\
\text { calcium phosphate }(29 \%) \text {, bis- } \\
\text { muth subcarbonate (21\%), } \\
\text { zirconium oxide (10\%), calcium } \\
\text { oxide }(4 \%)\end{array}$ \\
\hline \multirow[t]{2}{*}{ AHPlus } & $\begin{array}{l}\text { Dentsply, De } \\
\text { Trey, GmbH, } \\
\text { Konstanz, } \\
\text { Germany }\end{array}$ & $\begin{array}{l}\text { Paste A: Epoxy resin, cal- } \\
\text { cium tungstate, zirconium oxide, } \\
\text { aerosol, iron oxide }\end{array}$ \\
\hline & & $\begin{array}{l}\text { Paste B: Adamantane amine, } \\
\text { N,N-dibenzoly-5-oxanonana } \\
\text { TCD-diamine, calcium tungstate, } \\
\text { zirconium oxide, aerosol alicone } \\
\text { oil. }\end{array}$ \\
\hline
\end{tabular}

a flow rate of $50 \mathrm{ml} \mathrm{min}^{-1}$ in the temperature range of $25-1000^{\circ} \mathrm{C}$. The heating rate was $10^{\circ} \mathrm{C} \mathrm{min}{ }^{-1}$. Highly sintered- $\mathrm{Al}_{2} \mathrm{O}_{3}$ was used as the reference material.

\section{Results and discussion}

ESR is a useful method for direct detection of radical structures. The results obtained in these experiments were reproducible. Each experiment was repeated at least twice. No difference was observed in ESR results.

\subsection{ESR analysis of AHPlus and MM-Seal}

AHPlus sealer consists of two components which are AHPlus paste A and B. No ESR signals were observed from the paste $A$. The signals recorded from the paste B are shown in Fig. 1. It is clear that paste A, containing the epoxy resin, known as a very toxic agent [28, 29], does not has a radical structure. However paste B contains radical structure. Therefore, it might be said that polymerization reaction of AHPlus sealer is started by the paste B component. AHPlus samples in both freshly mixed and set conditions exhibited the same ESR signals. ESR measurements were performed on the polymerized AHPlus sealer sample between $25^{\circ} \mathrm{C}$ and $37^{\circ} \mathrm{C}$. It was observed that the shape of the spectra and their intensities were not affected by the change of temperature (Fig. 2). Figure 2 shows that the observed free radical is strongly immobilized. Considering Fig. 2 and the data in the literature [30], it can be said that the recorded spectrum looks like the spectrum of a nitroxyl radical. Investigations performed on nitroxyl radicals have shown that these radical structures may be destructive for living tissue [31].

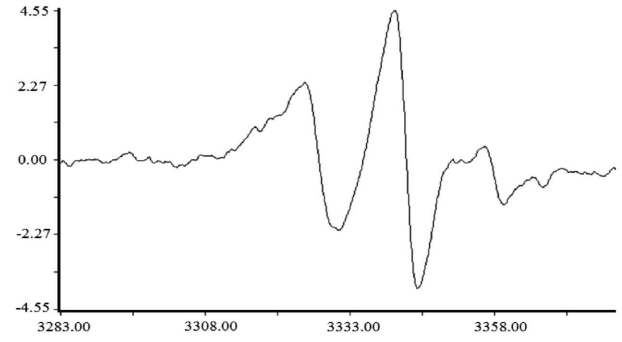

Fig. 1. ESR spectrum of the dried AHPlus paste B component.

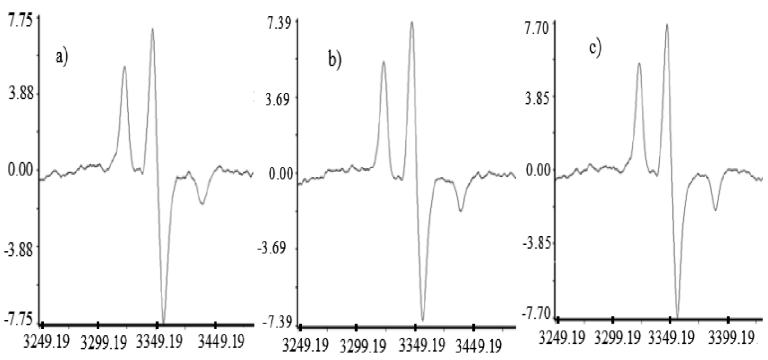

Fig. 2. ESR spectrum of the polymerized AHPlus sample at $0{ }^{\circ} \mathrm{C}(\mathrm{a}), 25^{\circ} \mathrm{C}(\mathrm{b}), 37^{\circ} \mathrm{C}(\mathrm{c})$.

MM-Seal samples were investigated in the same way. It was observed that the MM-Seal sample in both freshly mixed and set conditions exhibited the same ESR signals. ESR spectra were recorded from the set MM-seal between $25^{\circ} \mathrm{C}$ and $37^{\circ} \mathrm{C}$ (Fig. 3). It was observed that the radical structure in MM-seal was affected by the change of temperature. We do not have any knowledge about whether this new situation produced by temperature is dangerous for tissues or not. However, it is well known that radical structures may be dangerous for living cells [31].

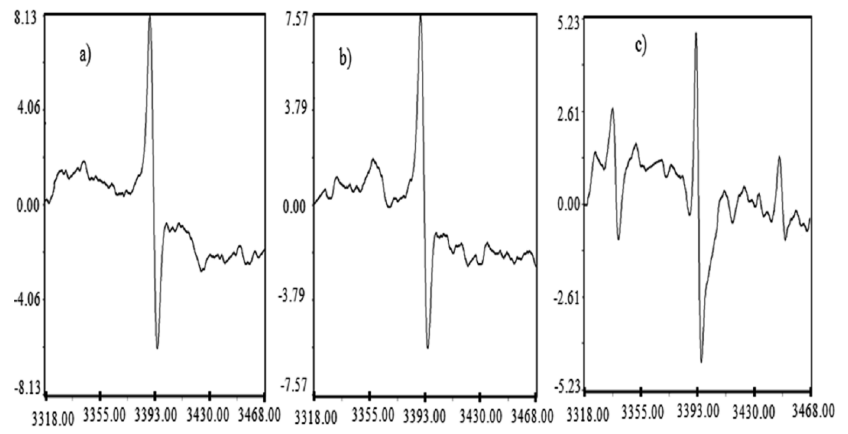

Fig. 3. ESR spectrum of the polymerized MM-Seal at $0{ }^{\circ} \mathrm{C}(\mathrm{a}), 25^{\circ} \mathrm{C}(\mathrm{b}), 37^{\circ} \mathrm{C}(\mathrm{c})$.

The radical concentration, which is proportional to unpaired electron concentration, was calculated (Fig. 4) using WINEPR software, from the area under the integrated curve. Figure 5 shows that the unpaired electron concentration in AHPlus was more than that of MM-Seal. The concentration on AHPlus changed slightly with 


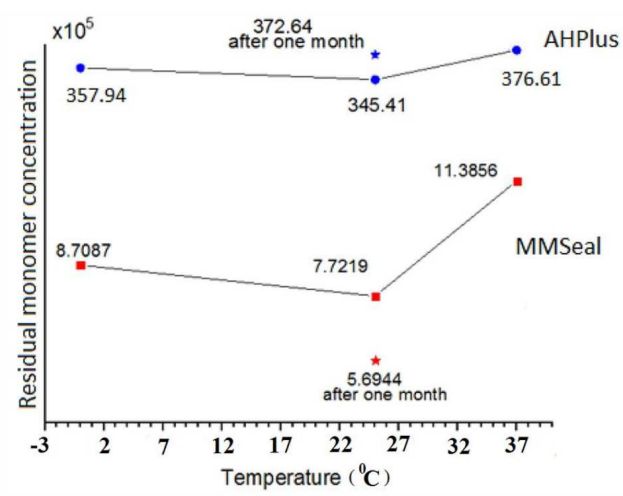

Fig. 4. Residual monomer concentration in the polymerized AHPlus and MM-Seal.
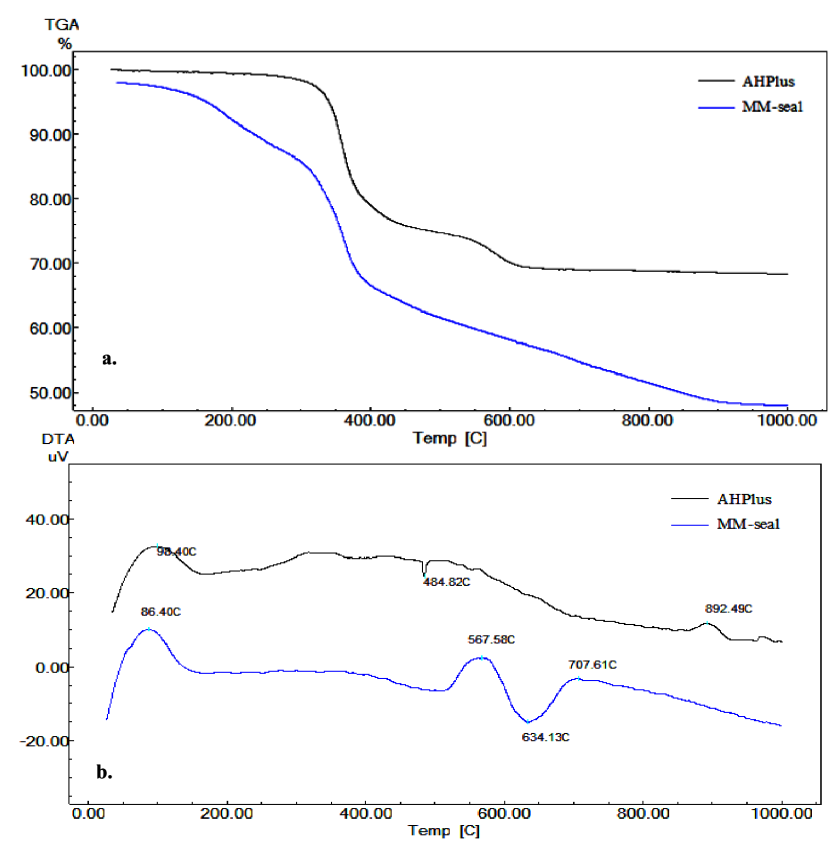

Fig. 5. (a) TGA curves of the polymerized AHPlus and MM-Seal. (b) DTA curves of the polymerized AHPlus and MM-Seal.

setting time, although the concentration in MM-Seal have decreased with the setting time. ESR measurements were performed on the set root canal sealers stored in a humid environment at $37^{\circ} \mathrm{C}$ during two months. After two months, no ESR signals were seen in both AHPlus and MMSeal samples. The obtained results show that the radical structures have disappeared; hence it might be said that toxic effects of the AHPlus and MM-Seal test samples disappear with time. The ESR parameter $(g$ value), calculated from experimental spectra for AHPlus and MM-Seal root canal sealers, are shown in Table II.

\subsection{Thermal analysis}

AHPlus and MM-Seal sealer polymerized samples were analyzed by thermogravimetry analysis (TGA) and
TABLE II

ESR parameters of AHPlus and MM-Seal.

\begin{tabular}{c|c}
\hline \hline & $g$-value \\
\hline \multicolumn{2}{c}{ After one day } \\
\hline AHPlus & 2.00385 \\
MM-Seal & 1.98386 \\
\hline \multicolumn{2}{c}{ After one month } \\
\hline AHPlus & 2.00385 \\
MM-Seal & 1.98386 \\
\hline
\end{tabular}

Note: The errors are estimated to be \pm 0.0005 for all calculated $g$.

differential thermal analysis (DTA) methods. Although decomposition of the AHPlus occurred in two steps, MM-Seal was decomposed in three steps. For AHPlus, first a part of the molecule was released from the structure in an endothermic step, then the residual structure was decomposed. Although no degradation took place until $264.87^{\circ} \mathrm{C}$, thermal degradation started above this temperature. For MM-Seal, first, a part of the molecule was released from the molecular structure in an endothermic step, then another part was released from the molecular structure in an endothermic step, and then the remaining structure was decomposed in an exothermic step. Decomposition has started at about $296.2^{\circ} \mathrm{C}$. The studies reported here give insight into the structural changes occurring as the root canal sealers are decomposed with temperature. Thermo-analytical results from TGA-DTA curves of the AHPlus and MM-Seal samples in flowing nitrogen atmosphere are shown in Fig. 5a and $b$.

\section{Conclusions}

It was found that AHPlus and MMSeal dental materials have stable radical structures. The radical concentration in AHPlus is higher than that of MM-seal. Additionally the concentration of radicals in AHPlus has changed slightly with time. In the thermal studies, it was observed that AHPlus material is less stable than MM-Seal. In the present ESR studies, it can be asserted that relative cytotoxicity of the materials can be evaluated by measurement of the radical concentration $[32,33]$. The literature has presented controversial opinion on the cytotoxicity of root canal materials [34-36]. Hence, further studies are necessary.

\section{Acknowledgments}

This study was partially supported by the Scientific Research Projects Coordination centers of Selcuk and Alanya Alaaddin Keykubat Universities, Konya, Antalya, Turkey.

\section{References}

[1] O. Zmener, J. Endod. 30, 348 (2004).

[2] F.M. Huang, K.W. Tai, M.Y. Chou, Y.C. Chang, Int. Endod. J. 35, 153 (2002). 
[3] V.B. Michelsen, G. Moe, M.B. Strom, E. Jensen, H. Lygre, Dent. Mater. 24, 724 (2008).

[4] A. Eckhardt, N. Gerstmayr, K.A. Hiller, C. Bolay, C. Waha, G. Spagnuolo, C. Camargo, G. Schmalz, H. Schweikl, Biomaterials 30, 2006 (2009).

[5] J. Durner, U.I. Walther, J. Zaspel, R. Hickel, F.X. Reichl, Biomaterials 31, 818 (2010).

[6] U.I. Walther, S.C. Walther, F.X. Reichl, R.I. Hicke, Arch. Oral Biol. 49, 125 (2004).

[7] P.T. Silva, F.G. Pappen, E.M. Souza, J.E. Dias, I. Bonetti Filho, I.Z. Carlos, R.T. Leonardo, Braz. Dent. J. 19, 228 (2008).

[8] S. Bouillaguet, J.C. Wataha, F.R. Tay, M.G. Brackett, P.E. Lockwood, J. Endod. 32, 989 (2006).

[9] M.D. Oztan, S. Yilmaz, A. Kalayci, L. Zaimoglu, J. Oral Rehabil. 30, 426 (2003).

[10] G. Lodiene, E. Morisbak, E. Bruzell, D. Qrstavik, Int. Endod. J. 41, 72 (2008).

[11] S.G. Pereira, J.P. Telo, T.G. Nunes, J. Mater. Sci. Mater. Med. 19, 3135 (2008).

[12] R.F. Khan, J. Pekar, W.J. Rink, D.R. Boreham, Radiat. Isot. 62, 173 (2005).

[13] G. Simeonov, A. Dragenov, D. Rustschev, J. Therm. Anal. 36, 721 (1990).

[14] H. Deligoz, O. Ozen, G. Koyundereli Cilgi, H. Cetisli, Thermochim. Acta 42, 33 (2005).

[15] Biological Evaluation of Dental Materials, Specification No: 41, American National Standards Institue/American Dental Association, June 1979.

[16] H.J. Shintani, Liq. Chromatogr. 18, 613 (1995).

[17] M. Pelka, W. Distler, A. Petchelt, Clin. Oral. Invest. 3, 194 (1999).

[18] M. Noda, H. Komatsu, H. Sano, Mater. Res. 47 , 374 (1999).

[19] K. Inoue, I. Hayashi, J. Oral. Rehabil. 9, 493 (1982).

[20] L. Shajii, J.P. Santerre, Biomaterials 20, 1897 (1999).

[21] A. Hamid, W.R. Hume, Dent. Mater. 13, 98 (1997).

[22] L.G. Lovell, S.M. Newman, C.N. Bowman, J. Dent. Res. 78, 1469 (1999).
[23] D. Nathanson, P. Lertpitayakun, S.M. Lamkin, M. Edalatpour, L.L. Chou, J. Am. Dent. Assoc. 128, 1517 (1997).

[24] R. Pulgar, S.F. Olea, F.A. Novillo, A. Rivas, P. Pazos, V. Pedraza, J.M. Navajas, N. Olea Environ. Health Perspect. 108, 21 (2000)

[25] I. Sideridou, V. Tserki, G. Papanastasiou, Biomaterials 23, 1819 (2002).

[26] I.E. Ruyter, Acta Odontol. Scand. 39, 27 (1981).

[27] F.A. Rueggeberg, D.H. Margeson, J. Dent. Res. 69, 1652 (1990).

[28] C. Klaassen, Heavy metals and heavy-metal antagonists in: Goodman and Gilman's the pharmacological basis of therapeutics, Eds. J. Hardman, L. Limbird, P. Molinoff, R. Ruddon, McGraw-Hill, New York 1998, p. 1649

[29] H. Schweikl, A. Hartmann, K.A. Hiller, G. Spagnuolo, C. Bolay, G. Brockhoff, G. Schmalz Dent. Mater. 23 , 688 (2007).

[30] A. Rajca, M. Vale, S. Rajca, J. Am. Chem. Soc. 130, 9099 (2008).

[31] A.G. McBride, V. Borutaité, G.C. Brown, Biochim Biophys Acta 1454, 275 (1999).

[32] T. Atsumi, S. Fujisawa, K. Satoh, H. Sakagami, I. Iwakura, T. Ueha, Y. Sugita, I. Yokoe, Anticancer res. 20, 2519 (2000)

[33] H. Okayasu, F. Suzuki, K. Satoh, S. Shioda, K. Dohi, Y. Ikeda, H. Nakashima, N. Komatsu, M. Fujimaki, K. Hashimoto, J. Maki, H. Sakagami, In Vivo 17, 577 (2003).

[34] G.T.B. Correa, G.A.C. Veranio, L.E. Silva, J.R. Hirata, J.M. Coil, M.F.Z. Scelza, J. Appl. Oral Sci. 17, 457 (2009).

[35] K.M. Karapinar, O.F. Bayrak, M.E. Yalvac, H. Ersev, J. Tanalp, F. Sahin, G. Bayirli, Int. Endod. J. 44, 626 (2011).

[36] M.G. Brackett, A. Marshall, P.E. Lockwood, J.B. Lewis, R.L.W. Messer, S. Bouillaguet, J.C. Wataha, Int. Endod. J. 41, 1072 (2008). 